\title{
Hematopoietic Progenitor Cell Antigen CD34
}

National Cancer Institute

\section{Source}

National Cancer Institute. Hematopoietic Progenitor Cell Antigen CD34. NCI Thesaurus.

Code $C 17280$

Hematopoietic progenitor cell antigen CD34 (385 aa, $41 \mathrm{kDa}$ ) is encoded by the human CD34 gene. This protein plays a role in cell-cell adhesion and may have a role in leukocyte migration. 